\title{
Three new alien Chenopodiaceae species in the flora of Russia
}

\author{
A. P. Sukhorukov ${ }^{1,2,5 *}$, E. A. Glazkova ${ }^{3,6}$, D. S. Shilnikov ${ }^{4,7}$, V. V. Shvanova ${ }^{3,8}$ \\ ${ }^{1}$ Moscow State University, Leninskiye Gory, 1/12, Moscow, 119234, Russian Federation \\ ${ }^{2}$ Tomsk State University, Lenina Pr., 36, Tomsk, 634050, Russian Federation \\ ${ }^{3}$ Komarov Botanical Institute RAS, Prof. Popova St., 2, St. Petersburg, 197376, Russian Federation \\ ${ }^{4}$ Perkalsky Dendrological Park of the Komarov Botanical Institute RAS, Pyatigorsk, \\ Stavropol Territory, 357506, Russian Federation \\ 5E-mail: suchor@mail.ru; ORCID iD: https://orcid.org/0000-0003-2220-826X \\ ${ }^{6}$ ORCID iD: https://orcid.org/0000-0003-4833-5953 \\ ${ }^{7}$ ORCID iD: https://orcid.org/0000-0001-9954-2181 \\ ${ }^{8}$ ORCID iD: https://orcid.org/0000-0002-5158-3096 \\ * Corresponding author
}

Keywords: alien species, Chenopodiastrum simplex, distribution, Dysphania carinata, Dysphania pumilo, invasions, vascular plants.

Summary. Three new alien species of Chenopodiaceae s. str. (Amaranthaceae s. 1.) are reported for the flora of Russia, the North American Chenopodiastrum simplex and Australian Dysphania carinata and D. pumilio. The identification of the specimens of Chenopodiastrum simplex from Moschny Island in the Leningrad Region (European Russia) was confirmed using both morphological and phylogenetic analyses. Morphologically, C. simplex is very similar to $C$. badachschanicum having the same fruit and seed characters. A single specimen of Dysphania carinata from Primorye Territory (the Russian Far East) was previously identified as Chenopodium pumilio (三 Dysphania pumilio) incorrectly. Only recently, the latter species has been indeed found in Beslan town, Republic of North Ossetia - Alania (the North Caucasus). For each species, the possible degree of naturalization is discussed.

\section{Три новых чужеродных вида из семейства Chenopodiaceae во флоре России}

\author{
А. П. Сухоруков ${ }^{1,2}$, Е. А. Глазкова ${ }^{3}$, Д. С. Шильников ${ }^{4}$ В. В. Шванова ${ }^{3}$ \\ ${ }^{1}$ Московский государственный университет, Ленинские Горы, д. 1-12, г. Москва,119234, Россия \\ ${ }^{2}$ Томский государственный университет, просп. Ленина, д. 36, г. Томск, 634050, Россия \\ ${ }^{3}$ Ботанический институт им. В. Л. Комарова РАН, ул. Проф. Попова, д. 2, г. Санкт-Петербург, 197376, Россия \\ ${ }^{4}$ Перкальский дендрологический парк Ботанического института им. В. Л. Комарова РАН, \\ пос. Энергетик, г. Пятигорск, 357506, Россия
}

Ключевые слова: инвазии, маревые, распространение, Россия, сосудистые растения, чужеродные виды. 
Аннотация. В статье приводятся три чужеродных вида, новых для флоры России: североамериканский вид Chenopodiastrum simplex и два австралийских - Dysphania carinata и D. pumilio. Определение образца Chenopodiastrum simplex с острова Мощный в Ленинградской области (Европейская Россия) подтверждено морфологическим и филогенетическим анализами. Морфологически C. simplex трудно отличим от C. badachschanicum, оба вида имеют схожие плоды и семена. Единственный образец Dysphania carinata из Приморского края (российский Дальний Восток) был ранее ошибочно определен как Chenopodium pumilio (三 Dysphania pumilio). Последний вид только недавно обнаружен в г. Беслане, Республика Северная Осетия-Алания (Северный Кавказ). Обсуждается возможная степень натурализации каждого вида.

\section{Introduction}

The Chenopodiaceae clade is recognized as a part of Amaranthaceae Juss. s. 1. after extensive molecular studies (e. g., Cuénoud et al., 2002, Kadereit et al., 2003; Brockington et al., 2009). The members of this clade play an important role in steppe, desert, and coastal vegetation types or are noxious weeds in temperate regions (e. g., Korovin, 1934; Danin, 1983; Australian vegetation, 1994; Busso, Bonvissuto, 2009). In Russia, the number of Chenopodiaceae species can provisionally be estimated as 180 (133 species in European Russia: Sukhorukov, 2014), but some difficult genera like Corispermum L. and Chenopodium L. have not been properly revised yet in the Asiatic part.

There are many articles reporting new alien Chenopodiaceae in different provinces of Russia. Such translocations are occurring from natural vegetation types to the north suffering habitat changes. In almost all cases, the species originate in the same continent (intracontinental introduction). The Central Asian species Atriplex laevis C. A. Mey., Axyris amaranthoides L., Corispermum declinatum Stephan ex Iljin, Salsola collina Pall., and Teloxys aristata (L.) Moq. are the most frequent invaders in different parts of European Russia (Sukhorukov, 2014) being synanthropic components of the flora. These examples do not include Chenopodiaceae crossing between continents. However, the vegetation in many subtropical regions is already facing a problem with naturalization of some Chenopodiaceae, especially Chenopodioideae from Australia, e. g. Atriplex inflata F. Muell., A. nummularia Lindl., A. suberecta Verdoorn to North and South Africa and South America (Maire, 1962; Germishuizen, Meyer, 2003; Brignone et al., 2016; APD, 2019) and Dysphania pumilio (R. Br.) Mosyakin et Clemants to Africa, South Europe, and the Americas (Uotila, Raus, Kalheber in Greuter, Raus, 2001 [with references therein]; Iamonico, 2011; USDA, NRCS, 2021; Uotila et al., 2021). The present article provides new information about the recent intercontinental introduction of three species of Chenopo- diaceae in different parts of Russia.

\section{Material and Methods}

The first author Alexander Sukhorukov (AS) has observed many native and alien Chenopodiaceae in different parts of the world, especially in European Russia (1997+), the Nepal Himalaya (2005-2015), and African countries (2009+). The morphological evaluation of the three species under consideration has also been provided by AS. The continuous field investigations were carried out in North-West Russia (the Leningrad Region) by Elena Glazkova $(1993+)$ who also paid special attention to alien species during field trips to the North Caucasus (2005) and the Far East (the Kuril Islands) (2019). Dmitry Shilnikov (DS) carried out the field studies in the North Caucasus (1999+) covered the Krasnodar Territory, Stavropol Territory, the Republics of Adygeya, Karachayevo-Circassian, Kabardino-Balkarian, North Ossetia - Alania, Daghestan (Russia) as well as Azerbaijan. Some other territories of Russia were also visited by DS. The identification of Chenopodiastrum simplex collected by E. Glazkova was also confirmed by the phylogenetic analysis that will be reported in another paper (Uotila et al., in prep.).

\section{Results}

Here we report three new alien species for Russia. Two of them, Dysphania carinata and D. pumilio, are from Australia, and the third species, Chenopodiastrum simplex, is from North America.

Chenopodiastrum simplex (Torrey) S. Fuentes, Uotila et Borsch, 2012, in Willdenowia 42: 12. Chenopodium hybridum var. simplex Torrey, 1828, in Ann. Lyceum Nat. Hist. New York 2: 239. $\equiv$ Chenopodium simplex (Torrey) Raf. 1832, in Atlantic J. 1: 146.

Holotype: "[USA, Nebraska / Iowa] Engineer cantonment near Council Bluffs, [1820], Dr. James" (NY). 
= Chenopodium gigantospermum Aellen, 1929, in Repert. Spec. Nov. Regni Veg. 26: 144. $\equiv$ Chenopodium hybridum subsp. gigantospermum (Aellen) Hultén, 1968, Ark. Bot. a. s. 7(1): 47. 三 Chenopodium hybridum var. gigantospermum (Aellen) Rouleau, 1944, Nat. Can. 71: 268.

Lectotype (Bassett, Crompton, 1982: 600): "Canada, British Columbia, Vernon. 9 VII 1889. J. Macoun 23329" (CAN, isolecto - US, DAO).

Morphology. For a detailed description see Basset, Crompton (1982, as Chenopodium gigantospermum). Related to Chenopodiastrum hybridum (L.) S. Fuentes, Uotila et Borsch and C. badachschanicum (Tzvelev) S. Fuentes, Uotila et Borsch. From the first species, $C$. simplex is easily differentiated by the loose pericarp and rugose seeds ( $C$. hybridum has adherent pericarp and foveolate seeds). Both C. simplex and C. badachschanicum possess the same carpological characters mentioned above. However, the leaves demonstrate some differences: they are ovate in outline, dentate or with attenuate lobes in $C$. simplex and usually triangular in $C . b a-$ dachschanicum.

To check the relationships in Chenopodiastrum and reveal the taxonomic status of a sample collected in the Leningrad Region, we conducted a more detailed phylogenetic analysis of the genus compared with the previous molecular trees (FuentesBazan et al., 2012). The results presented in Uotila et al. (in prep.) revealed that the sample from Russia falls within one subclade with another sample of C. simplex taken from North America.

Specimen seen. "NW Russia, Leningrad Region, Kingisepp distr., Gulf of Finland, Moschny Island (Lavansaari), NW part of the island, ca. $100 \mathrm{~m}$ south of Rybach'ya Bay (Suursatama), $60.02164^{\circ} \mathrm{N}$, $27.81434^{\circ} \mathrm{E}$. ruderal site, on sand heap, 1 exemplar. 16 VIII 2017. Elena Glazkova, EG-91" (LE 01072677!) (Fig. 1, 2).

Habitat. Chenopodiastrum simplex was found together with other alien species, e. g., Epilobium adenocaulon Hausskn., Bunias orientalis L., Medicago lupulina L., Cirsium vulgare (Savi) Ten., Bromus hordeaceus L., Carex spicata Huds., Melilotus albus Medik., Plantago media L., Matricaria discoidea DC., Carum carvi L., Sonchus asper (L.) Hill, Heracleum sphondylium L. subsp. sibiricum (L.) Simonk., Turritis glabra L., Spergularia rubra (L.) J. Presl et C. Presl, Capsella bursa-pastoris (L.) Medik., Trifolium hybridum L., Sisymbrium officinale (L.) Scop., Artemisia absinthium L., Arctium minus (Hill) Bernh., Senecio vulgaris L., Myosotis arvensis (L.) Hill.
General distribution. Temperate North America (USA and Canada); as casual alien in N and W Europe.

Dysphania carinata (R. Br.) Mosyakin et Clemants, 2002, Ukr. Bot. Zhurn. 59(4): 382. $\equiv$ Chenopodium carinatum R. Br. 1810, Prodr. Fl. Nov. Holland.: 407. 三 Salsola carinata (R. Br.) Spreng. 1824, Syst. Veg., ed. 16, 1: 923. $\equiv$ Ambrina carinata (R. Br.) Moq. 1840, Chenop. Monogr. Enum. 41. $\equiv$ Blitum carinatum (R. Br.) C. A. Mey. ex Steudel, 1840, Nom. Bot. $2^{\text {nd }}$ ed., 1: 210.

Holotype: "[Australia] New South Wales, Hawkesbury River, R. Brown s. n.” (BM!).

$=$ Chenopodium cristatum var. holopterum Thell. 1919, Vierteljahrsschr. Naturf. Ges. Zürich 64: 724. $\equiv$ Chenopodium holopterum (Thell.) Thell. et Aellen, 1928, Mitt. Naturf. Ges. Solothurn 20(8): 57. $\equiv$ Chenopodium carinatum var. holopterum (Thell.) Aellen, 1933, Verh. Naturf. Ges. Basel 44: 312.

Holotype: "Switzerland, Derendingen bei Solothurn, 1917, Probst s. n." (G);

$=$ Ambrina carinata var. parvifolia Moq. 1840, Chenop. Monogr. Enum. 42. 三Blitum glandulosum var. parvifolium (Moq.) Moq. 1849, in DC., Prodr. 13(2): 82 .

Lectotype (Wilson, 1984: 150): "[Australia] New South Wales, Port Jackson, D'Urville" (P).

$=$ Chenopodium carinatum f. foliosum Domin, 1921, Bibl. Bot. 89: 65.

Type: "[Australia] Queensland, Brisbane River, 1863, A. Dietrich 968" (PR?; iso - NSW, SING0057801).

Morphology. The description of this Australian species is available, e. g., in Wilson (1984). It has white, keeled and usually hairy perianth segments. As an alien species, it has been found in West and Central Europe (Aellen, 1961), but it seems to be rather scattered in Europe. A record of Chenopodium pumilio (Ignatov, 1988) (E Dysphania pumilio) indeed belongs to $D$. carinata.

Specimen seen. "Russian Far East, Primorsky Krai, Ussuriysky distr., Novo-Nikol'skoe vill. [Novonikol'sk], in the farm of «Kommunar» sovkhoz. 13 IX 1984. Buch et Shvydkaya, s. n." (MHA!) (Fig. 3, 4).

Habitat. Not mentioned on the label, but the specimen seems to have been collected in a ruderal site.

General distribution. Australia; as alien in W and C Europe, South America, southern Africa. 


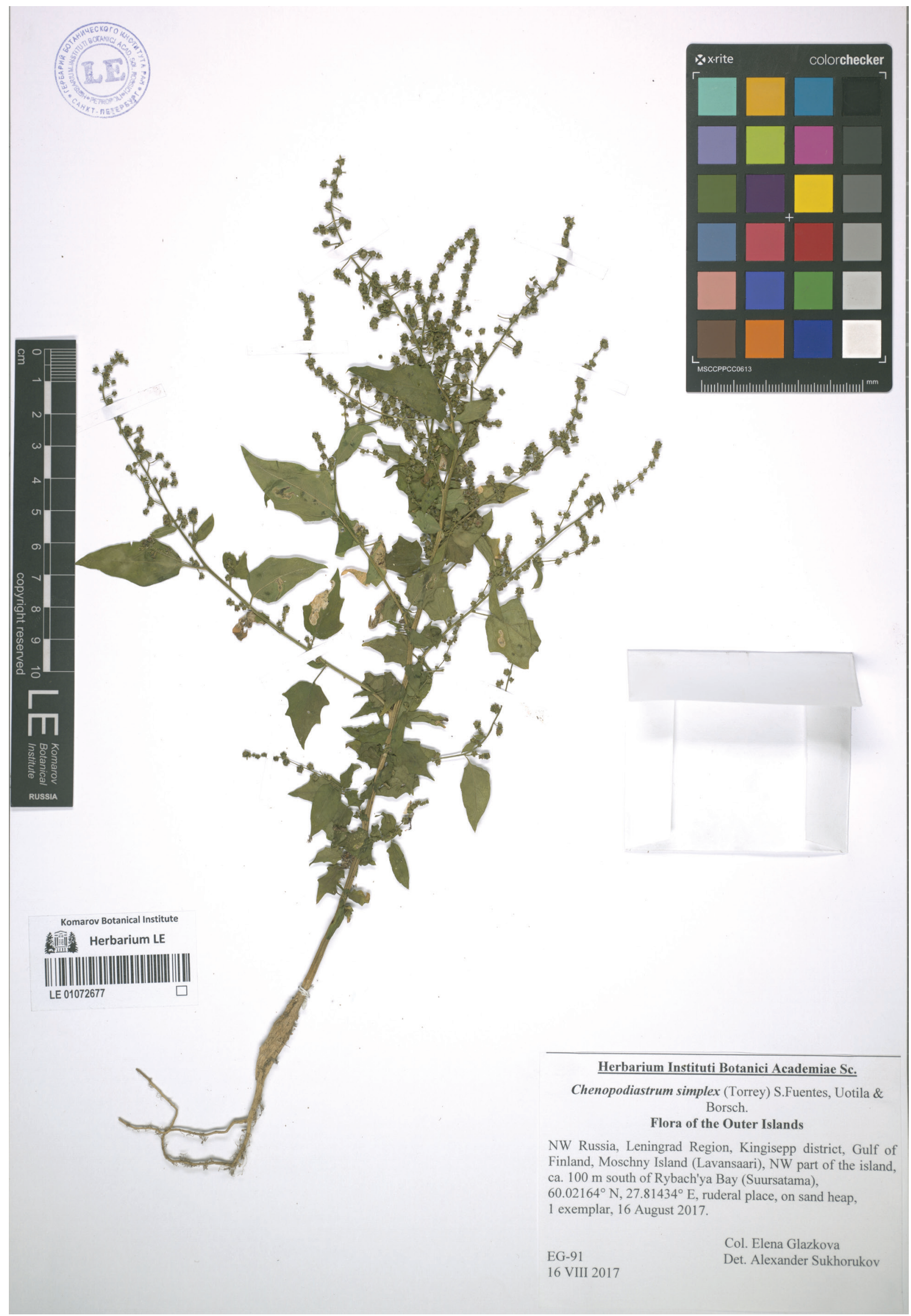

Fig. 1. Specimen of Chenopodiastrum simplex (LE). 


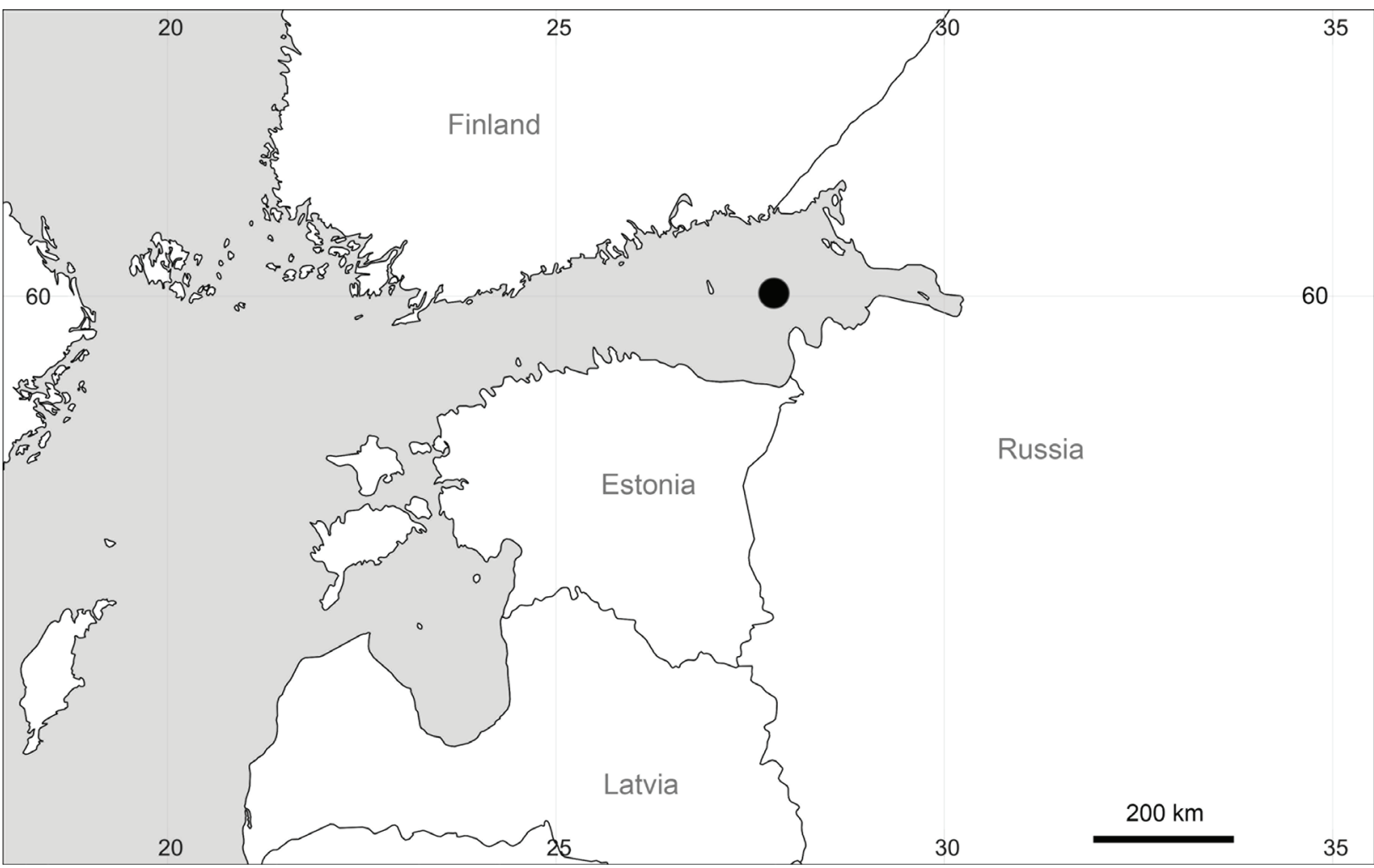

Fig. 2. A record of Chenopodiastrum simplex in Russia.

Dysphania pumilio (R. Br.) Mosyakin et Clemants, 2002, Ukr. Bot. Zhurn. 59(4): 382. 三 Chenopodium pumilio R. Br. 1810, Prodr. Fl. Nov. Holl. 1: 407. $\equiv$ Blitum pumilio (R. Br.) Moq. 1849, in DC., Prodr. 13(2): 82. $\equiv$ Ambrina pumilio (R. Br.) Moq. 1840, Chenop. Monogr. Enum.: 42. $\equiv$ Teloxys pumilio (R. Br.) W. A. Weber, 1985, Phytologia 58(7): 478.

Holotype: "Australia, Kangaroo Island, R. Brown" (BM! iso $-\mathrm{K}$ !).

= Blitum glandulosum Moq. 1849, in DC., Prodr. 13(2): 82. $\equiv$ Chenopodium glandulosum (Moq.) F. Muell. 1869, Fragm. 7: 11. $\equiv$ Chenopodium pumilio f. glandulosum (Moq.) Aellen, 1933, Verh. Naturf. Ges. Basel 44: 315.

Lectotype (designated here): "Blitum glandulosum Moq. Chenopodium. Nova Hollandia [Australia]. Ex herb. Desfont." (P00606458!).

Morphology. The description of this species is available, e. g., in Wilson (1984) and Sukhorukov (2014). Compared to Dysphania from Africa and Asia (see detailed investigations of Uotila, 2013; Sukhorukov, 2014; Sukhorukov, Kushunina, 2014; Sukhorukov et al., 2019; Uotila et al., 2021), this species has white (not green) incurved perianth segments and other reproductive characters. Compared with $D$. carinata, D. pumilio has slightly keeled (nor carinate or cristate), glabrous or slightly hairy perianth segments.

Specimen seen. "North Caucasus, North Ossetia - Alania Rep., Beslan town, Gor'ky St., N43ํ⒒822, E4433.348. 24 VII 2013. D. S. Shilnikov, s. n." (LE 01072678!) (Fig. 5, 6).

Habitat. A small population $\left(10 \mathrm{~m}^{2}\right)$ was found near a private house in a disturbed habitat, together with Polygonum arenastrum Boreau, Poa pratensis L., Plantago major L., and Taraxacum officinale F. H. Wigg.

General distribution. Australia; as alien and naturalized in N and S America, N, S and E Africa, South Europe, East Asia.

\section{Discussion}

The introduction with subsequent naturalization of alien species and possible transformation of natural and secondary habitats is one of the biggest problems in the biological sciences (Didham et al., 2005; Traveset, Richardson, 2006; Pyšek et al., 2017; Russell et al., 2017). In the Chenopodiaceae clade (Amaranthaceae s. 1.), some species, especially from Chenopodioideae, are widespread weeds in temperate regions of Eurasia, as well as being alien 


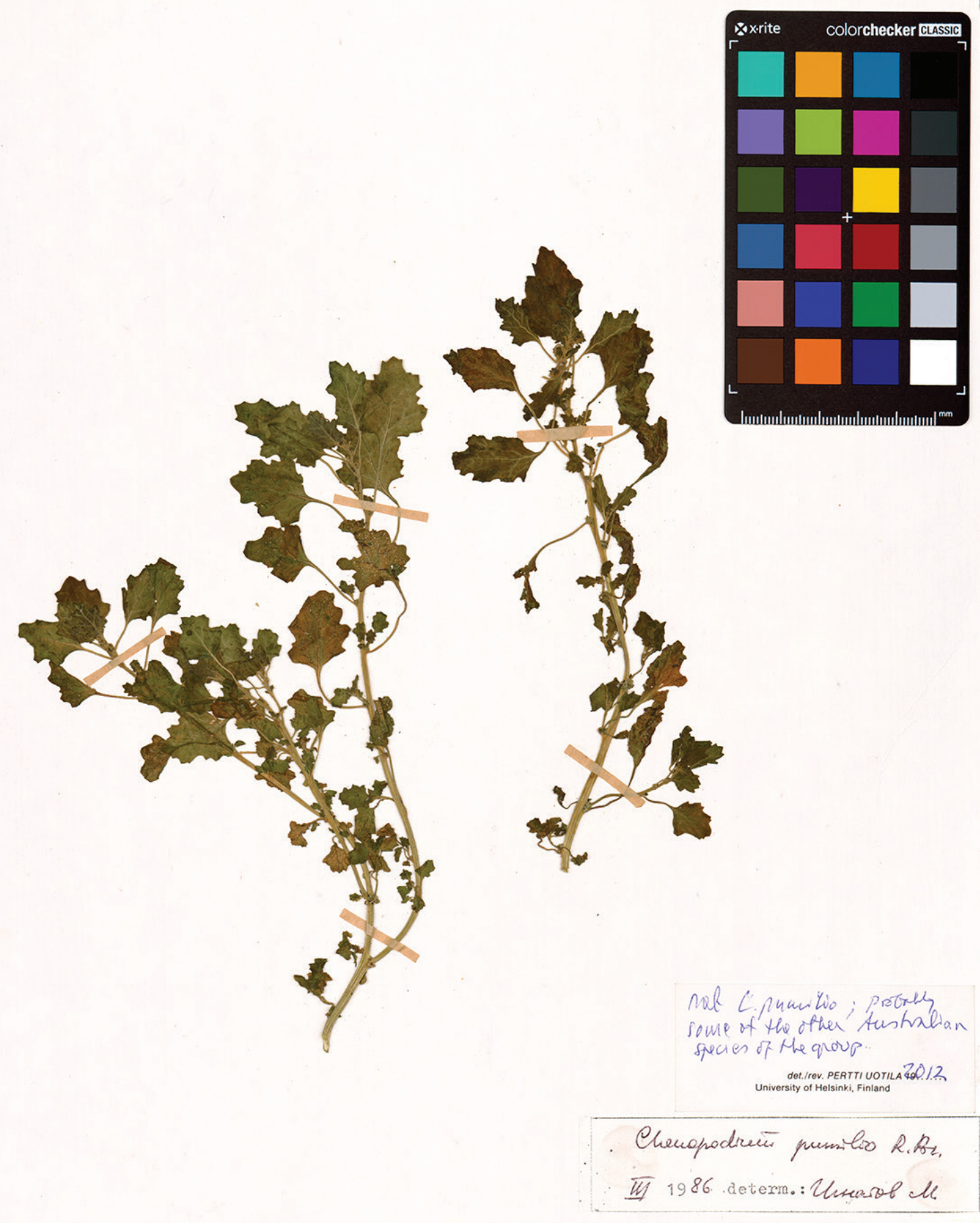

ДВНЦ АН СССР

БиолОГО-ПОчвенНЫЙ иНСТИТУТ Chenopodium

\begin{tabular}{|c|c|c|}
\hline \multirow[t]{4}{*}{ Место } & \multirow{2}{*}{\multicolumn{2}{|c|}{$\begin{array}{l}\text { сбора: } \\
\text { Припзорский край,У ссурийскини } \mathrm{p}-\mathrm{H} \text {, }\end{array}$}} \\
\hline & & \\
\hline & \multicolumn{2}{|c|}{ пос.Ново-НиЕолььекое, } \\
\hline & \multicolumn{2}{|c|}{ ферма совх. "Коммунар" } \\
\hline I3 & сентября 19 th $\mathrm{r}$. & Собр. Буч,Швыдғая \\
\hline & $198 \mathrm{r}$ & Onр. Бу ${ }_{3} T_{18} \Gamma_{1875}$ \\
\hline
\end{tabular}

Fig. 3. Specimen of Dysphania carinata (MHA). 
and naturalized in other continents. Chenopodium album L., C. vulvaria L., C. opulifolium Schrad. ex W. D. J. Koch et Ziz, Oxybasis glauca (L.) S. Fuentes, Uotila et Borsch (previously known as Chenopodium glaucum L.), Atriplex prostrata Boucher ex DC. originated from different regions of Eurasia and have been reported as alien in Australia (Wilson, 1984). A large number of Eurasian Chenopodiaceae with further naturalization were discovered in temperate South and North America (e. g., Aellen, 1929; Zappettini, 1953; Clemants, Mosyakin, 2003; Brignone et al., 2016; Jocou et al., 2020; Brignone, Denham, 2021). Similarly, many Australian and American Chenopodiaceae, especially different Chenopodium taxa (recently considered within the genera Chenopodium s. str., Blitum, Lipandra and Oxybasis: Fuentes-Bazan et al., 2012), were discovered in Europe especially in the first half of the $20^{\text {th }}$ century, mostly brought with wool and other goods (Aellen, 1929; Uotila, 2001). Here we pay special attention to the distribution of Chenopodiastrum simplex, Dysphania carinata and D. pumilio outside their natural range, with further categorization of their possible alien status.
Chenopodiastrum simplex is native to North America and seems to be a rare casual alien species in Europe known in Fennoscandia mostly from the first half of the $20^{\text {th }}$ century (Uotila, 2001). However, examination of herbarium collections in Vienna (W) by the first author (AS) showed the presence of plants with the same leaf and fruit/seed characters in Austria. According to GBIF (2019+), the species is also known from Germany, the Netherlands and Spain, but the corresponding records have not been checked by us. To date, the recent distribution of C. simplex in Europe requires further study. The report of C. simplex in Siberia (Lomonosova, 1992, as Chenopodium hybridum subsp. gigantospermum) is erroneous and a corresponding specimen belongs to C. badachschanicum (Tzvelev) S. Fuentes, Uotila et Borsch, a species widely distributed in Central Asia, South Siberia, the Himalaya and Tibet (Uotila et al., in prep.). Both species are morphologically similar, and the exact identification may be verified by phylogenetic analysis.

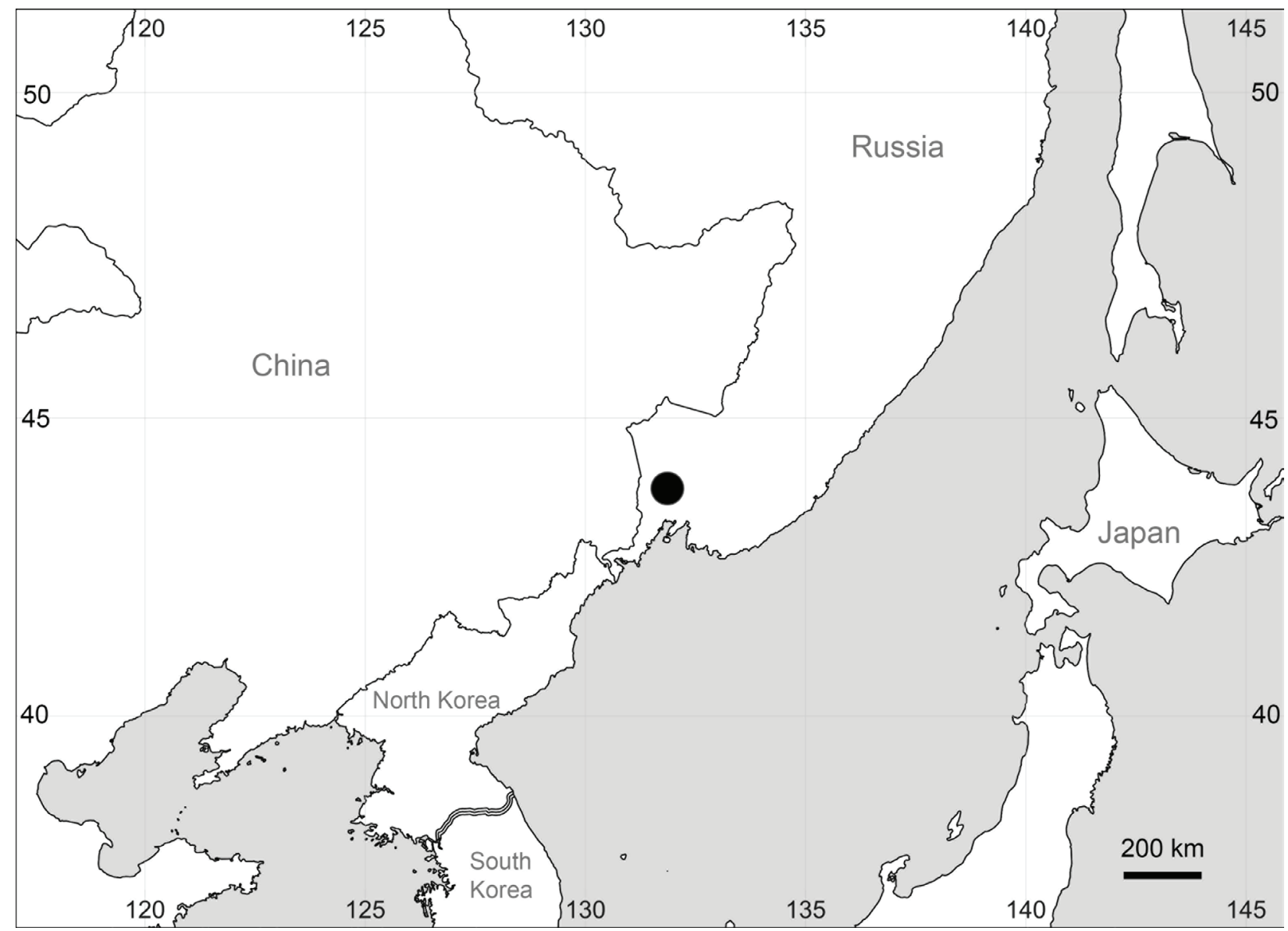

Fig. 4. A record of Dysphania carinata in Russia. 


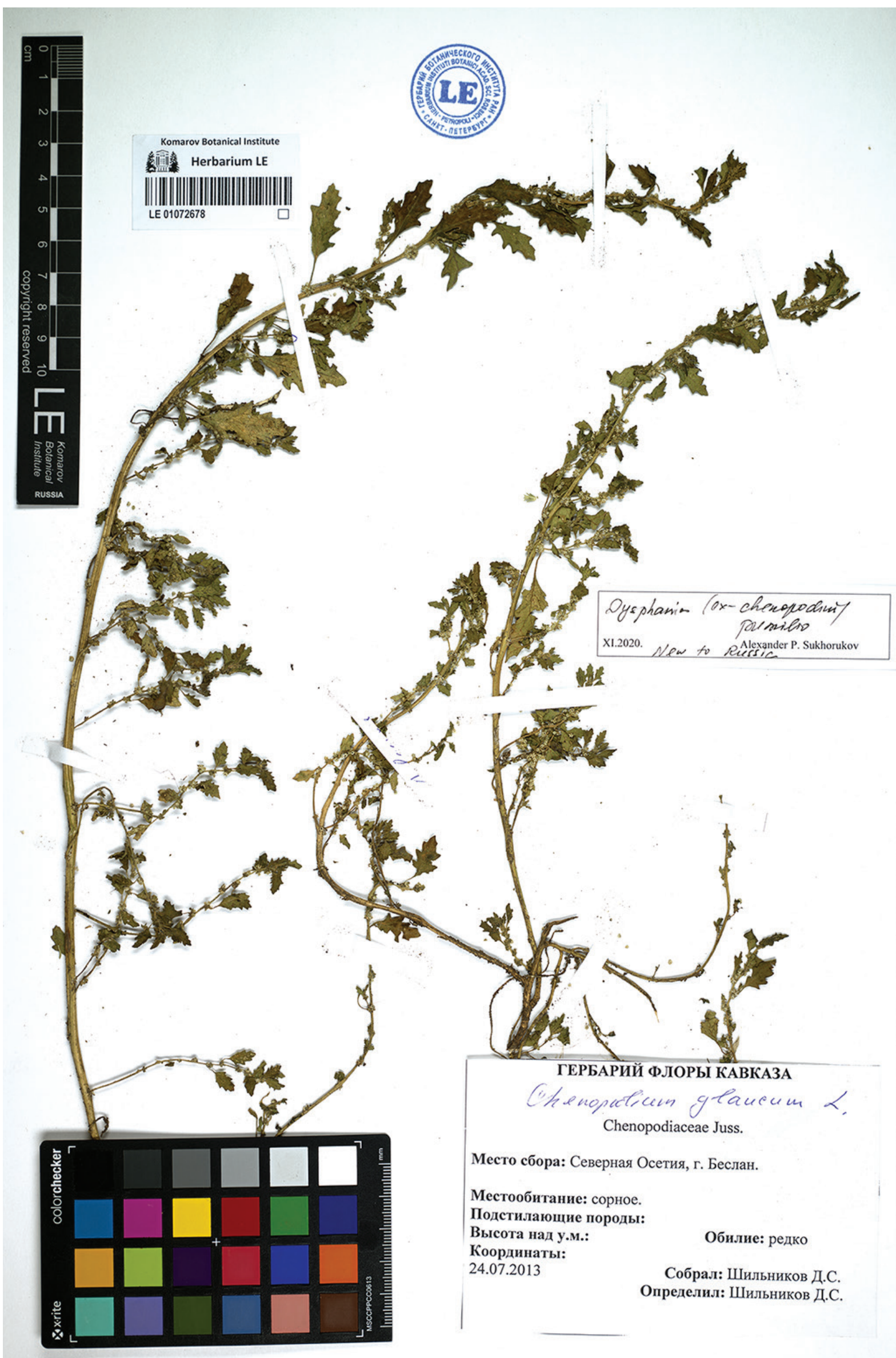

Fig. 5. Specimen of Dysphania pumilio (LE). 
Chenopodiastrum simplex seems to be a recent immigrant to the remote Moschny Island, since it was not found during previous expeditions to the islands of the Eastern Gulf of Finland (Glazkova, 2001). Although only one exemplar of $C$. simplex was found in August 2017, and it was not possible to visit this island later, the population may not be extinct owing to ability of many annual Chenopodioideae including Chenopodiastrum to form a viable soil seed bank for at least several years in conjunction with the carpological characteristics (different thickness of the seed-coat testa resulting in the heterospermous seeds) and physiological dormancy
(Sukhorukov, Zhang, 2013; Sukhorukov, 2014, with references therein). The introduction of $C$. simplex may be connected with crop import. Similarly, C. simplex was brought into Fennoscandia as a rare casual species with North American grain and soybeans (Uotila, 2001). The current status of C. simplex in Russia can be described as 'casual alien', as for some other rare exotic Chenopodiaceae in the Leningrad Region, e. g. Beta maritima L. and Atriplex oblongifolia Waldst. et Kit. found on the islands of the Gulf of Finland earlier (Glazkova, 2006; Sukhorukov, Uotila, 2007).

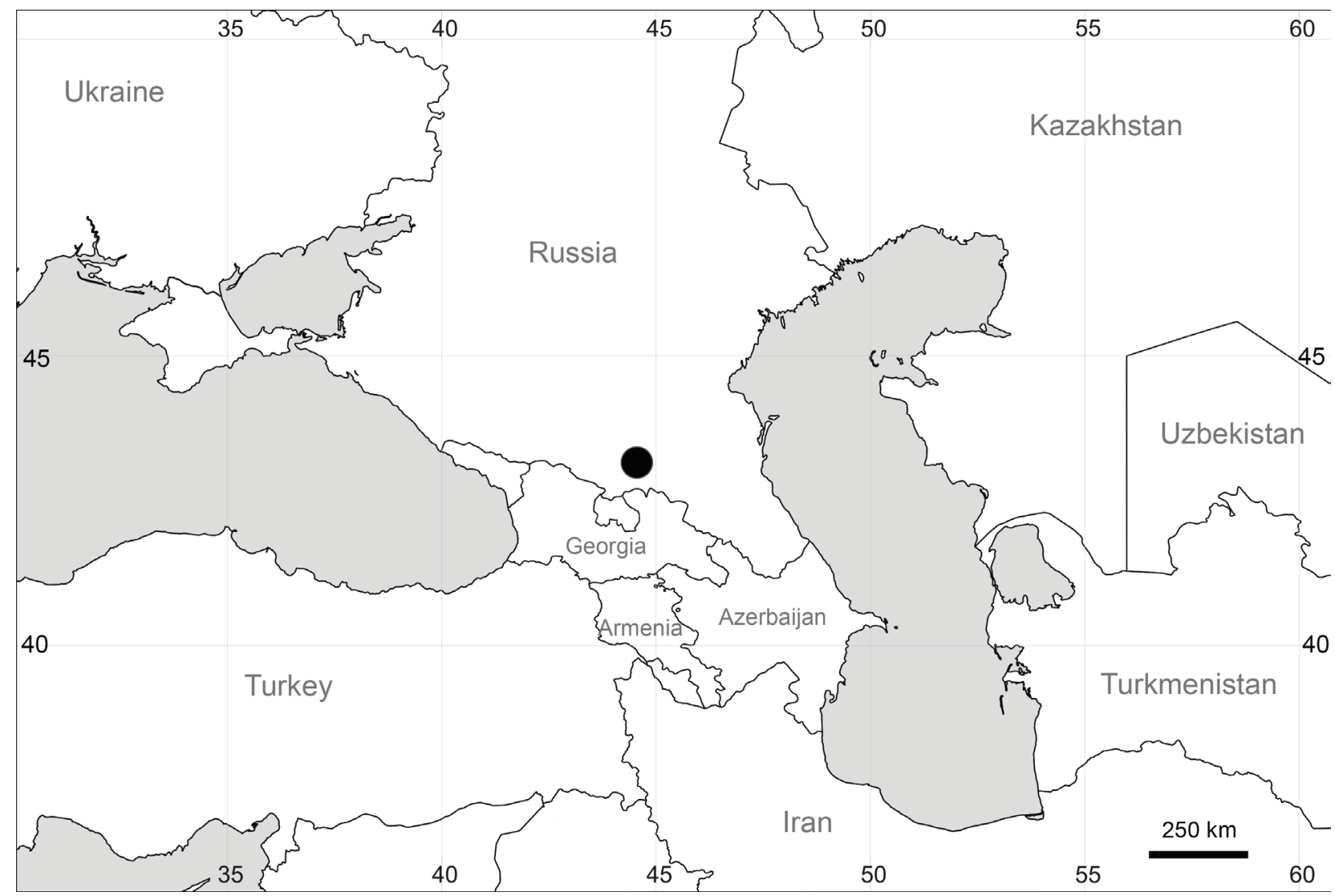

Fig. 6. A record of Dysphania pumilio in Russia.

The native distribution area of Dysphania carinata covers the easternmost part of Australia including Queensland, New South Wales and Victoria (Wilson, 1984). As an alien plant, it clearly prefers areas with arid climate, e. g., Namibia, where it mostly occupies dried-up river beds and can be considered as naturalized species (AS, pers. obs. in 2017-2018). In South Africa, it has been found in many regions (Germishuizen, Meyer, 2003). The records in other semi-arid and arid regions of Africa are still scattered (Brenan, 1954, 1988; APD, 2019; AS, pers. obs. and a specimen [MW] collected in
Tanzania in 2020). Dysphania carinata seems to be introduced in Europe in the late $19^{\text {th }}$ century with Australian wool (Aellen, 1929, as Chenopodium carinatum) and it is also reported in some parts of West, Central and North Europe (Uotila, 2011) and West Asia (Al-Turki, Ghafoor, 1996, as Chenopodium carinatum). However, this name is frequently misapplied to the closely related $D$. pumilio in many floras and checklists of Europe, another alien on the continent (Chytry, 1993). For this reason, the naturalization status of $D$. carinata has not been properly assessed, the records have not been mapped 
(Jalas, Suominen, 1980), and the species considered to be a casual alien (Uotila, 2011; Sukhorukov, 2014). In East Asia, it is reported from Japan (GBIF, 2019+), but at least some records refer to D. pumilio (Flora-Kanagawa Association, 2018; A. Sukhorukov, re-identifications in different herbaria). The reverse misidentification occurred in Ignatov (1988), when a specimen of $D$. carinata from the Primorye Territory of Russia was erroneously identified as $D$. pumilio. Thus, we exclude $D$. pumilio from the flora of the Russian Far East. Based on the scattered records of D. carinata in Eurasia, its naturalization in the Russian Far East seems to be impossible due to unsuitable climatic conditions (e. g., high precipitation, low winter temperatures).

Dysphania pumilio occurs as a native species mostly in southern Australia (Wilson, 1984) with further spreading as an alien into many subtropical regions of southern, central and eastern Africa (Brenan, 1954; Germishuizen, Meyer, 2003; Sukhorukov et al., 2016), Japan (Flora-Kanagawa Association, 2018), North and South America (Gleason, 1952 as Chenopodium pumilio; Clemants, Mosyakin, 2003; Funez et al. 2017; Brignone, 2020). At present, it is considered to be an invasive plant in North America (CABI, 2021). Knowledge of the occurrence and status of D. pumilio in Europe has changed dramatically. In the beginning of the $20^{\text {th }}$ century this species had not yet been noticed (Aellen, 1929) owing to confusion with $D$. carinata (re-identifications of the late P. Aellen and A. Sukhorukov in 2019, G!), but several decades later, it was being reported as an alien species in West and Central Europe (Aellen, 1961; Jalas, Suominen, 1980). The first collections from Central Europe are dated in 1870s (Aellen, 1961). Lhotská, Hejný (1979) reported the presence of a viable seed bank based on observations in the Czech Republic as well as different dispersal characteristics facilitating the naturalization of D. pumilio in Central Europe. To date, the alien status of D. pumilio has been changed to 'naturalized alien' in Central, South and East Europe (Ukraine) (Uotila, 2011). The recent detailed investigations confirm its naturalized and invasive status in at least some countries of South Europe, namely in Spain (Castroviejo, 1990; Uotila, 2011), Italy (Iamonico, 2011), and Serbia (Bogosavljević, Zlatković, 2017) being found in various disturbed habitats. According to observations by the first author (AS), $D . p u-$ milio is common in Barcelona (Spain) and Lisbon (Portugal) growing in asphalt cracks and sandy areas. First records of the species as a casual alien are known from Bulgaria (Grozeva, 2007) and Belarus
(Dzhus, 2011). Based on the literature data and our own observations, D. pumilio is able to naturalize in the countries with subtropical and warm temperate climate, and therefore further records of the species in Russia are expected in the North Caucasus and in the arid regions of European Russia.

\section{Conclusion}

The three species reported here have different alien status in the secondary distribution areas, and we assume their different naturalization status in Russia. Dysphania pumilio could potentially become a successful invader in ruderal sites in the southern part of European Russia and the North Caucasus.

\section{Acknowledgments}

The research of A. Sukhorukov was carried out in accordance with the scientific programe 121032500084-6 of the Department of Higher Plants (Lomonosov Moscow State University). The study of E. Glazkova and V. Shvanova was carried out within the framework of the research project no. AAAA-A 19-119031290052-1 (Vascular plants of Eurasia: systematics, flora, plant resources) of the Komarov Botanical Institute, RAS. The field investigations of E. Glazkova on Moschny Island in 2017 were supported by the Complex Expedition "Gogland" of the Russian Geographical Society, and she thanks the organizers and all participants of the expedition. We thank Geoffrey Harper for the proofread of the paper and Maria Kushunina for help in preparation of the final maps. We are also indebted to Pertti Uotila who paid our attention to an unusual specimen of Chenopodiastrum from Moschny Island. We also thank Marina Legchenko (LE) and Nina Stepanova (MHA) for the scanned images of Chenopodiastrum simplex and Dysphania carinata, respectively.

\section{Благодарности}

Исследования А. П. Сухорукова выполнены в соответствии с кафедральной темой государственного задания № 121032500084-6 (МГУ им. М. В. Ломоносова). Работа Е. А. Глазковой и В. В. Швановой выполнена в рамках государственного задания Ботанического института им. В. Л. Комарова РАН по плановой теме «Сосудистые растения Евразии: систематика, флора, растительные ресурсы» № AAAA-A19-119031290052-1. Полевые исследования Е. А. Глазковой на острове Мощный в 2017 г. проводились в составе и при 
поддержке Комплексной экспедиции «Гогланд» Русского географического общества. Е. А. Глазкова выражает благодарность организаторам и всем участникам экспедиции. Благодарим Дж. Харпера за вычитку английского текста и М. А. Кушунину за помощь в подготовке финальной версии карт. Мы также признательны П. Уотила, обратившему внимание на необычный образец Chenopodiastrum с острова Мощный. Мы также благодарим M. В. Легченко (LE) за сканирование образца Chenopodiastrum simplex и Н. Ю. Степанову (MНА) за сканирование образца Dysphania carinata.

\section{REFERENCES / ЛИTEPATУРA}

Aellen P. 1929. Beitrag zur Systematik der Chenopodium-Arten Americas, vorwiegend auf Grund der Sammlung des United States National Museum in Washington. Feddes Repertorium 26 (1-6, 7-15): 31-53; 119-160.

Aellen P. 1961. Chenopodiaceae. In: Illustrierte Flora von Mitteleuropa. Vol. 3 (2). Hegi G. (ed.), München. Pp. 533-747.

Al-Turki T. A., Ghafoor A. 1996. The genus Chenopodium L. in Saudi Arabia. Feddes Repertorium 107: 189-208.

APD (African Plant Database). 2019. Version 3.4.0. Conservatoire et Jardin botaniques de la Ville de Genève and South African National Biodiversity Institute. Pretoria. URL: http://www.ville-ge.ch/musinfo/bd/cjb/africa/ (Accessed 09 September 2019).

Australian vegetation. 1994. 2nd ed. R. H. Groves (Ed.). Cambridge: Cambridge University Press. 562 pp.

Basset I. J., Crompton C. W. 1982. The genus Chenopodium in Canada. Canadian Journal of Botany 60: 586-610. Bogosavljević S., Zlatković B. 2017. Dysphania pumilio (R. Br). Mosyakin \& Clemants (Amaranthaceae), a new allochthonous species in the flora of Serbia. Botanica Serbica 41(1): 83-87. DOI: 10.5281/zenodo.455155

Brenan J. P. M. 1954. Chenopodiaceae. In: Flora of Tropical East Africa. Vol. 7. W. B. Turrill, E. Milne-Redhead (eds). London: Crown Agents. Pp. 1-26.

Brenan J. P. M. 1964. Chenopodium [s. 1.]. In: Flora Europaea. Vol. 1. T. G. Tutin, V. H. Heywood, N. A. Burges, D. H. Valentine, S. M. Walters, D. A. Webb (eds). Cambridge: Cambridge University Press. Pp. 92-95.

Brenan J. P. M. 1988. Chenopodiaceae. In: Flora Zambesiaca. Vol. 9(1). E. Launert (Ed.). London: Crown Agents. Pp. 133-161.

Brignone N. F. 2020. Dysphania. In: Flora Argentina. Vol. 19(1). F. O. Zuloaga, M. J. Belgrano (eds). Buenos Aires: Talleres Trama S. A. Pp. 178-187.

Brignone N. F., Denham S. S. 2021. Toward an updated taxonomy of the South American Chenopodiaceae I: Subfamilies Betoideae, Camphorosmoideae, and Salsoloideae. Annals of the Missouri Botanical Garden 106: 10-30. DOI: $10.3417 / 2020615$

Brignone N. F., Denham S. S., Pozner R. 2016. Synopsis of the genus Atriplex (Amaranthaceae, Chenopodioideae) for South America. Australian Systematic Botany 29: 324-357. DOI: 10.1071/SB16026

Brockington S. F., Alexandre R., Ramdial J., Moore M. J., Crawley S., Dhingra A., Hilu K., Soltis D. E., Soltis P. S. 2009. Phylogeny of the Caryophyllales sensu lato: Revisiting hypotheses on pollination biology and perianth differentiation in the core Caryophyllales. International Journal of Plant Sciences 170(5): 627-643. DOI: 10.1086/597785

Busso C. A., Bonvissuto G. L. 2009. Structure of vegetation patches on northwestern Patagonia, Argentina. Biodiversity \& Conservation 18: 3017-3041.

CABI. 2021. Invasive Species Compendium. Wallingford: CAB International. URL: www.cabi.org/isc

Castroviejo S. 1990. Chenopodiaceae. In: Flora Iberica. Vol. 2. S. Castroviejo, M. Laínz, G. López González, P. Montserrat, F. Muñoz Garmendia, J. Paiva, L. Villar (eds). Madrid: Real Jardín Botánico. Pp. 476-553.

Chytry M. 1993. Chenopodium pumilio R. Br., a new adventive species for Romania. Linzer Biologische Beiträge 25(1): 151-152.

Clemants S. E., Mosyakin S. I. 2003. Dysphania. In: Flora of North America, North of Mexico. Vol. 4. S. I. Welsh, C. M. Crompton, S. E. Clemants (eds). New York-Oxford: Oxford University Press. Pp. 267-275.

Cuénoud P., Savolainen V., Chatrou L. W., Powell M., Grayer R. J., Chase M. W. 2002. Molecular phylogenetics of Caryophyllales based on nuclear 18S rDNA and plastid rbcL, atpB, and matK DNA sequences. American Journal of Botany 89(1): 132-144. DOI: 10.3732/ajb.89.1.132

Danin A. 1983. Desert vegetation of Israel and Sinai. Jerusalem: Cana Publishing House. 148 pp.

Didham R. K., Tylianaki S. J. M., Hutchison M. A., Ewers R. M., Gemmell N. J. 2005. Are invasive species the drivers of ecological change? Trends in Ecology and Evolution 20(9): 470-474. DOI: 10.1016/j.tree.2005.07.006

Dzhus M. A. 2011. Clammy goosefoot (Dysphania pumilio (R. Br.) Mosyakin et Clemants, Amaranthaceae Juss.) new adventive species to the Belarusian flora. Vestnik Vitebskogo gosudarstvennogo universiteta [Proceedings of the Vitebsk State University] 5(65): 28-33. [In Russian] (Джус М. $\boldsymbol{A}$. Дисфания низкая (Dysphania pumilio (R. Br.) 
Mosyakin et Clemants, Amaranthaceae Juss.) - новый адвентивный вид во флоре Беларуси // Вестник Витебского государственного университета, 2011. № 5(65). С. 28-33).

Flora-Kanagawa Association (ed.). 2018. Flora of Kanagawa. Vol. 2. Odawara: Kanagawa Prefectural Museum of Natural History.

Fuentes-Bazan S., Uotila P., Borsch T. 2012. A novel phylogeny-based generic classification for Chenopodium sensu lato, and a tribal rearrangement of Chenopodioideae (Chenopodiaceae). Willdenowia 42(1): 5-24. DOI: 10.3372/wi.42.42101

Funez L. A., Hassemer G., Ferreira J. P. R., Bones F. L. V., dos Santos A. P. 2017. Fifty-five new records of vascular plants, and other discoveries for the flora of Santa Catarina, southern Brazil. Webbia 72(2): 221-275. DOI: 10.1080/00837792.2017.1369303

GBIF [Global Biodiversity Information Facility]. 2019+. Backbone Taxonomy. Checklist dataset: Chenopodiastrum simplex: https://doi.org/10.15468/39omei; Dysphania carinata: https://doi.org/10.15468/39omei (Accessed via GBIF.org on 2021-03-18).

Germishuizen G., Meyer N. L. 2003. Plants of southern Africa: an annotated checklist. Strelitzia 14: 1-1231.

Glazkova E. A. 2001. Flora ostrovov vostochnoy chasti Finskogo zaliva: sostav $i$ analiz [Flora of the island of the Eastern Gulf of Finland: structure and analysis]. St. Petersburg: St. Petersburg University Press. 348 pp. [In Rus$\operatorname{sian]~(Глазкова~} \boldsymbol{E} . \boldsymbol{A}$. Флора островов восточной части Финского залива: структура и анализ. СПб.: Изд-во С.-Петерб. ун-та, 2001. 348 с.).

Glazkova E. A. 2006. Beta maritima (Chenopodiaceae) - a new species for the flora of Russia. Bot. Zhurn. 91(1): 34-45. [In Russian] (Глазкова E. A. Beta maritima (Chenopodiaceae) - новый вид для флоры России // Бот. журн., 2006. T. 91, № 1. C. 34-45).

Gleason H. A. 1952. The new Britton and Brown illustrated flora of the northeastern US and adjacent Canada. Vol. 2. New York \& London: Hafner. 655 pp.

Greuter W., Raus Th. (eds). 2001. Med-Checklist Notulae, 20. Willdenowia 31(2): 319-328. DOI: 10.3372/ wi.31.31204

Grozeva N. 2007. Chenopodium pumilio (Chenopodiaceae): a new species to the Bulgarian flora. Phytologia Balcanica 13(3): 331-334.

Iamonico D. 2011. On the presence of Dysphania pumilio (R. Br.) Mosyakin \& Clemants (Amaranthaceae) in Italy. Lagascalia 31: 175-183.

Ignatov M. S. 1988. Chenopodiaceae. In: Vascular plants of the Soviet Far East. Vol. 3. Chenopodiaceae. Leningrad: Nauka. Pp. 15-37. [In Russian] (Игнатов М. С. Сосудистые растения советского Дальнего Востока. Т. 3. Chenopodiaceae. Ленинград: Наука, 1988. С. 15-37).

Jalas J., Suominen J. 1980. Atlas Florae Europaeae. Vol. 5. Chenopodiaceae to Basellaceae. Helsinki: Helsingin Liikekirjapaino Oy. 119 pp.

Jocou A. I., Minué C. R., Brignone N. F., Gandullo R. 2020. Going unnoticed for 40 years: about the presence of the exotic Suaeda paradoxa (Chenopodiaceae, Suaedoideae) in Argentina. Phytotaxa 450(2): 219-228. DOI: 10.11646/phytotaxa.450.2.7

Kadereit G., Borsch T., Weising K., Freitag H. 2003. Phylogeny of Amaranthaceae and Chenopodiaceae and the evolution of C4 photosynthesis. International Journal of Plant Sciences 164: 959-986. DOI: 10.1086/378649

Korovin E. P. 1934. Vegetation of the Middle Asia and the southern Kazakhstan. Moscow; Tashkent. 479 pp. [In Russian] (Коровин Е. П. Растительность Средней Азии и южного Казахстана. М.-Ташкент, 1934. 479 с.).

Lhotská M., Hejný S. 1979. Chenopodium pumilio in Czechoslovakia: Its strategy of dispersal and domestication. Folia Geobotanica \& Phytotaxonomica 14(4): 367-375. DOI: 10.1007/bf02854930

Lomonosova M. N. 1992. Chenopodium [s. 1.]. In: Flora Sibiri [Flora of Siberia]. Vol. 5. Salicaceae - Amaranthaceae. Novosibirsk: Nauka. Pp. 138-149. [In Russian] (Ломоносова М. Н. Chenopodium // Флора Сибири: в 14 т. T. 5. Salicaceae - Amaranthaceae. Новосибирск: Наука, 1992. С. 138-149).

Maire R. 1962. Flore de l'Afrique du Nord. Vol. 8. Paris: Lechevalier. 303 pp.

Pyšek P., Pergl J., Essl F. et al. 2017. Naturalized alien flora of the world: Species diversity, taxonomic and phylogenetic patterns, geographic distribution and global hotspots of plant invasion. Preslia 89(3): 203-274. DOI: 10.23855/preslia.2017.203

Russell J. C., Meyer J.-Y., Holmes N. D., Pagad Sh. 2017. Humans and island environments invasive alien species on islands: impacts, distribution, interactions and management. Environmental Conservation 44(4): 359-370. DOI: $10.1017 / \mathrm{S} 0376892917000297$

Sukhorukov A. P. 2014. The carpology of the Chenopodiaceae with reference to the phylogeny, systematics and diagnostics of its representatives. Tula: Grif \& co. 400 pp. [In Russian] (Сухоруков А. П. Карпология семейства Chenopodiaceae в связи с проблемами филогении, систематики и диагностики его представителей. Тула: Гриф и К, 2014. 400 с.).

Sukhorukov A. P., Uotila P. 2007. Additions and corrections to the alien Chenopodiaceae flora of Finland and NW Russia. Memoranda Societatis pro Fauna et Flora Fennica 83(2): 53-58. 
Sukhorukov A. P., Kushunina M. A. 2014. Taxonomic revision of Chenopodiaceae in Nepal. Phytotaxa 191(1): 10-44. DOI: $10.11646 /$ phytotaxa.191.1.2

Sukhorukov A. P., Kushunina M. A., Verloove F. 2016. Notes on Atriplex, Oxybasis and Dysphania (Chenopodiaceae) in West-Central Tropical Africa. Plant Ecology and Evolution 149(2): 249-256. DOI: 10.5091/plecevo.2016.1181

Sukhorukov A. P., Liu P., Kushunina M. 2019. Taxonomic revision of Chenopodiaceae in Himalaya and Tibet. Phytokeys 116: 1-141. DOI: 10.3897/phytokeys.116.27301

Sukhorukov A., Zhang M. 2013. Fruit and seed anatomy of Chenopodium and related genera (Chenopodioideae, Chenopodiaceae/Amaranthaceae): implications for evolution and taxonomy. Plos One 8(4): e61906. DOI: 10.1371/ journal.pone.0061906

Traveset A., Richardson D. M. 2006. Biological invasions as disruptors of plant reproductive mutualisms. Trends in Ecology and Evolution 21(4): 208-216. DOI: 10.1016/j.tree.2006.01.006

Uotila P. 2001. Chenopodiaceae. In: Flora Nordica. Vol. 2: Chenopodiaceae to Fumariaceae. B. Jonsell (Ed.) Stockholm: The Bergius Foundation. Pp. 1-57.

Uotila P. 2011. Chenopodiaceae (pro parte majore). In: Euro +Med Plantbase - the information resource for EuroMediterranean plant diversity. URL: https://ww2.bgbm.org/EuroPlusMed/results.asp

Uotila P., Sukhorukov A. P., Bobon N., McDonald J., Krinitsina A. A., Kadereit G. 2021. Phylogeny, biogeography and systematics of Dysphanieae (Amaranthaceae). Taxon 70(3). In press. DOI: 10.1002/tax.12458

USDA, NRCS. 2021. The PLANTS Database. National Plant Data Team, Greensboro, NC 27401-4901 USA. URL: http://plants.usda.gov (Accessed 09 September 2019).

Wilson P. G. 1984. Chenopodiaceae. In: Flora of Australia. Vol. 4. A. S. George (Ed.). Canberra: Australian Government Publishing Service. Pp. 81-317.

Zappettini G. 1953. The taxonomy of Halogeton glomeratus. American Midland Naturalists 50(1): $238-247$. 